\title{
Hubungan Infeksi Protozoa Intestinal dengan Status Gizi Murid Sekolah Dasar di Kecamatan Ulakan Tapakis Kabupaten Padang Pariaman
}

Fitri Julianti ${ }^{1}$, Selfi Renita Rusjdi ${ }^{2}$, Abdiana $^{3}$

\begin{abstract}
Abstrak
Infeksi protozoa intestinal merupakan salah satu masalah kesehatan masyarakat di beberapa negara di dunia, terutama di daerah tropik dan subtropik termasuk Indonesia. Infeksi protozoa usus dapat menyebabkan gangguan dalam penyerapan zat gizi sehingga dapat mempengaruhi pertumbuhan dan perkembangan anak. Tujuan penelitian ini adalah menentukan hubungan infeksi protozoa intestinal dengan status gizi. Desain penelitian ini adalah cross sectional study. Telah dilakukan penelitian terhadap 83 murid di SDN 02 dan 012 di Kecamatan Ulakan Tapakis, Kabupaten Padang Pariaman pada Desember 2014 sampai Februari 2015. Hasil penelitian ini menunjukkan bahwa frekuensi infeksi protozoa intestinal adalah sebesar 16,9\%. Berdasarkan indeks BB/U, anak yang tergolong gizi kurang yaitu sebesar $44,6 \%$, sedangkan menurut indeks TB/U, anak yang tergolong pendek sebesar $45,8 \%$. Anak yang kurus berdasarkan indeks BB/TB didapatkan sebesar 15,7\%. Hasil uji statistik, didapatkan bahwa tidak ada hubungan yang bermakna antara kejadian infeksi protozoa intestinal dengan status gizi berdasarkan indeks BB/U $(p=0,622), T B / U(p$ $=0,958)$ dan BB/TB $(p=0,620)$. Disimpulkan bahwa prevalensi gizi kurang masih tergolong tinggi pada murid SD di Kecamatan Ulakan Tapakis. Tidak terdapat hubungan antara infeksi protozoa usus dengan status gizi murid SD di Kecamatan Ulakan Tapakis.
\end{abstract}

Kata Kunci: infeksi protozoa intestinal, status gizi, antropometri, anak sekolah dasar

\begin{abstract}
Intestinal protozoan infection is one of the public health problems in several countries in the world, especially in tropical and subtropical regions, including Indonesia. Intestinal protozoan infections can cause interference in the absorption of nutrients resulting in the disturbance of the growth and development of children. The objective of this study was to determine the relationship between intestinal protozoan infection and nutritional status. The design for this study was cross sectional. This study was conducted on 83 students of SDN 02 and 12 in Ulakan Tapakis SubDistrict, Regency of Padang Pariaman from December 2014 to February 2015. The results showed that the frequency of intestinal protozoan infections is $16.9 \%$. Based on the weight/age index, children classified as underweight is $44.6 \%$, while according to the height/age index, children classified as short is $45.8 \%$. The children were underweight based on the weight/height index was $15.7 \%$. The result of statistical test showed no significant correlation between the incidence of intestinal protozoan infection and nutritional status based on the weight/age $(p=0.622)$, height/age $(p=$ 0.958), and weight/height $(p=0.620)$ index. In conclusion, the prevalence of malnutrition is still high. There is no correlation between the incidence of intestinal protozoan infection and nutritional status.
\end{abstract}

Keywords: intestinal protozoa infection, nutritional status, antropometry, primary school children

Affiliasi penulis: 1. Prodi Profesi Dokter FK Unand (Fakultas Kedokteran Universitas Andalas Padang), 2. Bagian Parasitologi FK Unand, 3. Bagian IImu Kesehatan Masyarakat FK Unand
Korespondensi: Fitri Julianti, Email: fitrijulianti29@ymail.com, Telp:085271433005 


\section{PENDAHULUAN}

Infeksi protozoa intestinal masih menjadi masalah di beberapa negara di dunia. Hal ini dibuktikan dengan prevalensi yang masih tinggi dan tersebar luas di daerah tropik maupun subtropik termasuk Indonesia. Infeksi ini terjadi pada wilayah dengan tingkat sosioekonomi rendah dan ditunjang oleh hygiene sanitasi penduduk yang buruk. ${ }^{1}$

Berdasarkan penelitian yang dilakukan di Meksiko, didapatkan prevalensi Giardia lamblia sebesar $6,3 \%$, E. coli $23,1 \%$, dan B. hominis $22,4 \%{ }^{2}$ Hasil studi lain yang dilakukan terhadap 342 anak sekolah di Nepal menunjukkan 68 orang (19,8\%) terinfeksi protozoa intestinal. Jenis protozoa yang paling banyak ditemukan pada penelitian tersebut adalah Entamoeba coli, kemudian diikuti oleh Giardia lamblia, Entamoeba histolytica, Blastocystis hominis dan Endolimax nana. ${ }^{3}$ Penelitian lainnya di daerah Pahang Malaysia didapatkan prevalensi protozoa intestinal yang cukup tinggi, yaitu sebesar $85 \% .{ }^{4}$

Tingginya angka kejadian infeksi parasit usus di Indonesia dibuktikan dengan beberapa penelitian, seperti penelitian di Panti Asuhan, di Pondok Gede, Bekasi didapatkan prevalensi infeksi parasit usus masih cukup tinggi yaitu $37 \%$ dengan frekuensi tertinggi $B$. hominis sebesar $31 \% .^{5} \mathrm{Di}$ Yogyakarta didapatkan prevalensi protozoa intestinal sebesar $62,68 \%$ untuk daerah pedesaan dan 36,99\% untuk daerah perkotaan. ${ }^{6}$ Di Sumatera Barat, penelitian terhadap 66 anak binaan rumah singgah "Amanah", Kecamatan Padang Barat, Padang menunjukkan bahwa anak-anak yang terinfeksi protozoa intestinal sebesar $40,91 \%{ }^{7}$

Berdasarkan penelitian yang dilakukan terhadap 442 murid sekolah dasar di Bogota Colombia tahun 2006 didapatkan bahwa infeksi protozoa Giardia lamblia berhubungan dengan malabsorbsi dan terjadinya stunting pada anak (rendahnya z-score tinggi badan menurut usia). ${ }^{2}$ Penelitian terhadap 374 anak yang berumur 7-12 tahun di daerah pedesaan Malaysia didapatkan rata-rata berat badan pada anak yang menderita Giardia lamblia secara signifikan lebih rendah dari berat badan anak yang tidak terinfeksi Giardia lamblia. Rata-rata tinggi badan pada penderita Giardia lamblia juga lebih rendah dari rata-rata tinggi anak yang tidak terinfeksi, namun perbedaannya tidak terlalu signifikan. ${ }^{8}$

Dampak dari infeksi parasit usus, termasuk protozoa usus bersifat kronis dimana membutuhkan waktu yang lama untuk menimbulkan gejala yang nyata sehingga sering diabaikan oleh masyarakat. Infeksi parasit usus dapat menyebabkan hambatan pertumbuhan dan perkembangan anak (gangguan status gizi), bahkan untuk dampak jangka panjang bisa mengakibatkan penurunan daya pikir, penurunan prestasi dan produktivitas. $^{9}$

Infeksi protozoa intestinal tinggi pada anak umur 6-12 tahun. ${ }^{5}$ Tingginya infeksi parasit tersebut pada anak usia sekolah disebabkan karena beberapa kebiasaan seperti kebiasaan tidak mencuci tangan sebelum makan, kebiasaan menggigit kuku atau menghisap jari pada anak dan kebiasaan tidak memotong kuku 1 kali seminggu. ${ }^{9}$

Survey awal yang dilakukan terhadap 33 siswa di SDN. No 02 Ulakan Tapakis Kabupaten Padang Pariaman terdapat 5 siswa yang positif ditemukan protozoa intestinal. Di sekitar pemukiman warga terdapat anak sungai yang sering digunakan warga untuk buang air besar, sehingga ditakutkan air maupun lingkungan disekitar sungai tersebut dapat tercemar oleh kista protozoa.

Hasil survey awal yang dilihat dari beberapa SD di Ulakan Tapakis tersebut, masih terlihat cukup banyak anak yang berperawakan kurus. Di wilayah ini belum pernah dilakukan penelitian lebih lanjut untuk mengetahui hubungan infeksi protozoa intestinal dengan status gizi pada usia anak sekolah dasar.

Tujuan penelitian ini adalah menentukan hubungan antara infeksi protozoa intestinal dengan status gizi murid Sekolah Dasar di Kecamatan Ulakan Tapakis Kabupaten Padang Pariaman.

\section{METODE}

Penelitian ini merupakan jenis penelitian analitik dengan pendekatan cross sectional. Penelitian dilakukan dari Desember 2014 sampai Juni 2015.

Populasi pada penelitian ini adalah semua murid di SDN 02 dan SDN 12 Ulakan Tapakis, Kabupaten Padang Pariaman, Provinsi Sumatera Barat yang berjumlah 312 orang. 
Subjek dalam penelitian ini adalah sebagian populasi yang memenuhi kriteria inklusi dan eksklusi. Kriteria inklusi adalah anak yang bersedia ikut dalam penelitian ini, anak yang membawa pot tinja pada hari pengumpulan feses. Kriteria eksklusi penelitian ini adalah ditemukannya telur dan atau cacing dewasa pada tinja. Besar sampel diambil dengan menggunakan metode total sampling, dimana subjek yang memenuhi kriteria inklusi dimasukkan dalam penelitian yaitu sebanyak 312 orang.

Variabel penelitian terdiri dari infeksi protozoa intestinal dan status gizi.

Analisis data pada penelitian ini menggunakan analisis univariat untuk melihat distribusi frekuensi, analisis bivariat digunakan untuk melihat hubungan variabel independen dengan variabel dependen. Variabel independen adalah infeksi protozoa intestinal dan variabel dependen adalah status gizi. Untuk melihat hubungan kedua variabel tersebut dilakukan uji Chi-square dengan $p<0,05$ dan tingkat kepercayaan $95 \%$.

\section{HASIL}

\section{Analisis Univariat}

Jumlah responden dalam penelitian ini adalah sebanyak 83 orang, sedangkan 187 murid tidak datang pada hari pembagian ataupun tidak mengumpulkan pot feses. Sebanyak 42 murid dinyatakan terinfeksi cacing.

Tabel 1 menunjukkan bahwa sebagian besar murid yang menjadi subjek pada penelitian ini berusia $8-<10$ tahun (45\%). Jumlah murid yang berjenis kelamin perempuan adalah 48 orang $(57,8 \%)$ dan murid laki-laki berjumlah 35 orang $(42,2 \%)$. Dari 83 murid didapatkan 14 murid $(16,9 \%)$ terinfeksi protozoa intestinal. Giardia lamblia merupakan jenis protozoa intestinal yang paling banyak ditemukan, yaitu sebanyak 10 orang (12\%). Pada tabel tersebut, juga dapat dilihat bahwa murid yang memiliki status gizi normal adalah sebanyak 46 orang $(55,4 \%)$ dan gizi kurang sebanyak 37 orang (44,6\%). Jika dilihat berdasarkan indeks Tinggi Badan/Umur (TB/U) dan Berat Badan/Tinggi Badan (BB/TB), sebagian besar responden juga memiliki status gizi normal, yaitu sebesar $54,2 \%$ (TB/U) dan $84,3 \%$ (BB/TB).
Tabel 1. Karakteristik responden

\begin{tabular}{|c|c|c|c|}
\hline & & f & $\%$ \\
\hline Umur (tz & hun) & & \\
\hline$<7$ & & 4 & 4,8 \\
\hline $7-<8$ & & 12 & 14,5 \\
\hline $8-<9$ & & 19 & 22,9 \\
\hline $9-<10$ & & 19 & 22,9 \\
\hline $10-<11$ & & 12 & 14,5 \\
\hline$>11$ & & 17 & 20,5 \\
\hline Jenis Ke & lamin & & \\
\hline Laki-laki & & 35 & 42,2 \\
\hline Perempu & & 48 & 57,8 \\
\hline Infeksi F & rotozoa Intestinal & & \\
\hline Positif & & 14 & 16,9 \\
\hline - & Giardia Iamblia & 10 & 12,0 \\
\hline - & Entamoeba histolytica & 3 & 3,6 \\
\hline - & Balantidium coli & 0 & 0 \\
\hline- & Isospora belli & 0 & 0 \\
\hline- & G.lamblia+E.coli & 1 & 1,2 \\
\hline Negatif & & 69 & 83,1 \\
\hline Status $C$ & izi (BB/U) & & \\
\hline Kurang & & 37 & 44,6 \\
\hline Normal & & 46 & 55,4 \\
\hline Status C & izi (TB/U) & & \\
\hline Pendek & & 38 & 45,8 \\
\hline Normal & & 45 & 54,2 \\
\hline Status C & izi (BB/TB) & & \\
\hline Kurus & & 13 & 15,7 \\
\hline Normal & & 70 & 84,3 \\
\hline Total & & 83 & 100 \\
\hline
\end{tabular}

\section{Analisis Bivariat}

Hubungan antara infeksi protozoa intestinal dengan status gizi didapatkan melalui analisis dengan proses komputerisasi menggunakan Chi-Square Test.

Tabel 2. Hubungan kejadian infeksi protozoa intestinal dengan status gizi berdasarkan indeks BB/U

\begin{tabular}{|c|c|c|c|c|c|c|c|}
\hline Infeksi & & atus $\mathrm{C}$ & ii (B & (U) & & tal & \\
\hline Protozoa & & ang & & mal & & & p \\
\hline Intestinal & $f$ & $\%$ & $f$ & $\%$ & f & $\%$ & \\
\hline Positif & 5 & 35,7 & 9 & 64,3 & 14 & 100 & 0,662 \\
\hline Negatif & 32 & 46,4 & 37 & 53,6 & 69 & 100 & \\
\hline Total & 37 & 44,6 & 46 & 55,4 & 83 & 100 & \\
\hline
\end{tabular}


Tabel 2 menunjukkan bahwa kejadian infeksi protozoa intestinal yang positif dengan gizi kurang sebanyak 5 orang $(35,7 \%)$, sedangkan kejadian infeksi protozoa intestinal yang positif dengan status gizi normal yaitu sebanyak 9 orang $(64,3 \%)$. Setelah dilakukan uji statistik didapatkan bahwa tidak terdapat hubungan yang bermakna ( $p>0,05)$ antara kejadian infeksi protozoa intestinal dengan status gizi berdasarkan indeks BB/U.

Tabel 3. Hubungan kejadian infeksi protozoa intestinal dengan status gizi berdasarkan indeks TB/U

\begin{tabular}{lccccc}
\hline Infeksi & \multicolumn{4}{c}{ Status Gizi (TB/U) } & p \\
\cline { 2 - 5 } $\begin{array}{l}\text { Protozoa } \\
\text { Intestinal }\end{array}$ & \multicolumn{2}{c}{ Pendek } & \multicolumn{2}{c}{ Normal } & \\
\cline { 2 - 5 } & $\mathbf{f}$ & $\%$ & $\mathbf{f}$ & $\%$ & \\
\hline Positif & 7 & 50,0 & 7 & 50,0 & 0,958 \\
Negatif & 31 & 44,9 & 38 & 55,1 & \\
\hline Total & 38 & 45,8 & 45 & 54,2 & \\
\hline
\end{tabular}

Tabel 3 menunjukkan bahwa persentase murid yang positif terinfeksi protozoa intestinal yang tergolong pendek sama dengan murid yang memiliki status gizi normal, yaitu masing-masing sebanyak 7 orang $(50 \%)$. Setelah dilakukan uji statistik, ternyata tidak didapatkan adanya hubungan yang bermakna ( $p$ $>0,05)$ antara kejadian infeksi protozoa intestinal dengan status gizi berdasarkan indeks TB/U.

Tabel 4. Hubungan kejadian infeksi protozoa intestinal dengan status gizi berdasarkan indeks BB/TB

\begin{tabular}{lccccc}
\hline Infeksi & \multicolumn{3}{c}{ Status Gizi (BB/TB) } & \multirow{2}{*}{ p } \\
\cline { 2 - 5 } $\begin{array}{l}\text { Protozoa } \\
\text { Intestinal }\end{array}$ & \multicolumn{2}{c}{ Kurus } & \multicolumn{2}{c}{ Normal } & \\
\cline { 2 - 5 } & $\mathbf{f}$ & $\%$ & $\mathbf{f}$ & $\%$ & \\
\hline Positif & 2 & 14,3 & 12 & 85,7 & 0,620 \\
Negatif & 11 & 15,9 & 58 & 84,1 & \\
\hline Total & 13 & 15,7 & 70 & 84,3 & \\
\hline
\end{tabular}

Tabel 4 menunjukkan bahwa murid yang positif terinfeksi protozoa intestinal lebih banyak yang memiliki proporsi badan normal $(85,7 \%)$, sedangkan pada anak yang kurus sebanyak 2 orang (14,3\%). Uji statistik, didapatkan bahwa tidak terdapat hubungan yang bermakna $(p>0,05)$ antara kejadian infeksi protozoa intestinal dengan status gizi indeks BB/TB.

\section{PEMBAHASAN}

Hasil analisis univariat diketahui bahwa murid yang menderita infeksi protozoa intestinal adalah sebanyak 14 orang (16,9\%). Berdasarkan jenisnya, spesies protozoa yang paling banyak ditemukan adalah infeksi Giardia lamblia sebanyak 10 orang (12 \%), diikuti dengan infeksi Entamoeba histolytica sebanyak 3 orang $(26,7 \%)$, dan infeksi campuran hanya 1 orang $(6,7 \%)$.

Penelitian yang dilakukan di kabupaten Hulu Sungai Utara, Kalimantan Selatan terhadap 1.520 penduduk, sebanyak $40,4 \%$ dinyatakan positif terinfeksi protozoa usus patogen. ${ }^{1}$ Frekuensi ini jauh lebih tinggi dibandingkan frekuensi protozoa intestinal pada penelitian ini. Hasil penelitian ini juga berbeda dengan penelitian di daerah pedesaan Yogyakarta yang mendapatkan frekuensi protozoa intestinal sebesar $62,68 \%{ }^{6}$

Perbedaan hasil penelitian ini dapat disebabkan oleh beberapa hal, antara lain faktor sanitasi lingkungan dan hygiene perorangan seperti kebiasaan tidak mencuci tangan sebelum makan, tidak memotong kuku satu kali seminggu, serta tidak mencuci sayuran atau buah-buahan mentah sebelum dimakan. Jika seseorang hanya menderita infeksi derajat ringan, maka parasit sulit terdeteksi pada teknik pemeriksaan feses secara apusan langsung. ${ }^{10}$

Hasil analisis univariat status gizi menunjukkan anak yang memiliki status gizi kurang, yaitu sebanyak 37 orang $(44,6 \%)$, sedangkan yang gizinya normal yaitu sebanyak 46 orang $(55,4 \%)$. Berdasarkan indeks $\mathrm{TB} / \mathrm{U}$, didapatkan anak yang tergolong pendek sebanyak 38 orang $(45,8 \%)$ dan normal sebanyak 45 orang $(54,2 \%)$. Berdasarkan indeks BB/TB, didapatkan hasil 70 anak mengalami gizi normal $(84,3 \%)$ dan 13 anak (15,7\%) tergolong kurus.

Hasil penelitian ini sejalan dengan penelitian di Kecamatan Lawongan Barat terhadap 70 orang murid SD yang juga menunjukkan sebagian besar memiliki status gizi normal jika dilihat berdasarkan indeks $\mathrm{BB} / \mathrm{U}, \mathrm{TB} / \mathrm{U}$ dan BB/TB, yaitu masing-masing sebanyak $94,2 \%, 88,6 \%$ dan $91,4 \%{ }^{11}$

Pada umunya responden pada penelitian ini juga memiliki gizi normal tetapi banyak juga yang memiliki gizi kurang ataupun pendek, maka dari itu 
status gizi pada anak SD di Kecamatan Ulakan Tapakis perlu diperhatikan. Ada beberapa faktor yang dapat mempengaruhi status gizi, seperti : asupan makanan dan penyakit infeksi. ${ }^{12}$

Asupan makanan selain ditentukan oleh pendidikan dan status sosial ekonomi keluarga, juga ditentukan oleh kebiasaan makan dan kandungan zat gizi dalam makanan. ${ }^{12}$ Jika status sosial ekonomi rendah maka kebutuhan makan keluarga akan kurang terpenuhi sehingga anak akan memiliki gizi kurang. ${ }^{13}$

Hal lain yang dapat mempengaruhi asupan makan anak adalah kebiasaan makan, seperti anak yang malas makan dan kebiasaan anak makan dalam porsi yang jauh dari kecukupan gizi. ${ }^{14}$ Pola makan yang disertai kebiasaan makan yang tidak baik merupakan salah satu penyebab timbulnya masalah gizi. $^{15}$

Faktor ketiga yang dapat mempengaruhi asupan makan anak adalah kandungan zat gizi dalam makanan. Pola konsumsi yang dianjurkan di Indonesia mengarah pada pola konsumsi yang lebih beragam, bergizi dan berimbang yang biasa disebut menu seimbang yang terdiri dari makanan pokok, lauk hewani dan nabati, sayur, buah dan susu. Pada kenyataannya banyak faktor yang dapat mengakibatkan banyak keluarga tidak dapat memenuhi pola konsumsi tersebut, seperti : faktor ekonomi sebuah keluarga, ketersediaan pangan, pendidikan atau pengetahuan orang tua mengenai gizi seimbang dan sosial budaya. ${ }^{15}$

Ada beberapa faktor yang menjadi kemungkinan menjadi penyebab tingginya angka kekurangan gizi pada murid SDN 02 dan 12 Ulakan Tapakis, seperti status sosial ekonomi, pola makan dan kebiasaan makan anak. Selain itu, adanya kemungkinan menderita penyakit kronik dan penyakit yang disebabkan parasit usus seperti cacing dan protozoa juga dapat mempengaruhi status gizi anak.

Analisis dengan uji chi-square menunjukkan tidak terdapat hubungan yang bermakna $(p>0,05)$ antara kejadian infeksi protozoa intestinal dengan status gizi pada murid SDN 02 dan 012 di Kecamatan Ulakan Tapakis tersebut berdasarkan indeks BB/U.
Hasil penelitian ini sama dengan penelitian di Malaysia yang menunjukkan bahwa infeksi Giardia lamblia tidak berhubungan dengan status gizi seseorang berdasarkan indeks $B B / U .{ }^{16}$ Keadaan ini bisa disebabkan karena gejala klinis yang timbul pada penderita infeksi Giardia lamblia sangat bervariasi dan berbeda antara penderita, hal ini tergantung pada jumlah kista yang tertelan, lamanya infeksi, faktor hospes dan parasitnya sendiri. ${ }^{17}$ Jika jumlah kista yang tertelan sedikit dan infeksi yang terjadi belum berlangsung lama maka gejala yang ditimbulkan oleh infeksi Giardia lamblia hanya ringan dan dapat sembuh spontan, biasanya tidak sampai menimbulkan penurunan berat badan sehingga tidak begitu mempengaruhi keadaan gizi seseorang secara akut.

Sindroma malabsorbsi yang disebabkan oleh infeksi Giardia lamblia baru akan terjadi dalam fase kronik. Kerusakan mukosa intestinal yang disebabkan oleh infeksi parasit ini dapat menyebabkan defisiensi beberapa enzim pencernaan, seperti laktase, silase dan sukrase. Perubahan pada struktur mukosa usus halus ini biasanya membutuhkan waktu yang lama. ${ }^{17}$

Analisis penelitian menggunakan uji chi-square menunjukkan bahwa tidak terdapat hubungan yang bermakna $(p>0,05)$ antara kejadian infeksi protozoa intestinal dengan status gizi pada murid SDN 02 dan 012 di Kecamatan Ulakan Tapakis tersebut berdasarkan indeks TB/U.

Indeks TB/U merupakan indeks antropometri yang menggambarkan pertumbuhan skeletal. Berbeda dengan berat badan, pengaruh defisiensi zat gizi terhadap tinggi badan baru akan terjadi dalam waktu yang relatif lama. ${ }^{12}$

Hasil penelitian ini berbeda dengan penelitian di Colombia yang menunjukkan bahwa Giardia lamblia berhubungan dengan rendahnya status gizi berdasarkan indeks TB/U. ${ }^{2}$ Penyakit yang disebabkan oleh parasit biasanya bersifat kronik dan perubahan patologisnya juga terjadi sangat lambat. ${ }^{18}$ Perubahan patologis ini yaitu berupa kerusakan mikrovili usus yang mengakibatkan gangguan absorbsi nutrien. Jika keadaan ini terjadi dalam waktu yang lama, maka akan mengakibatkan gangguan pertumbuhan. ${ }^{17}$ 
Perbedaan hasil penelitian ini bisa disebabkan karena banyak faktor yang dapat mempengaruhi dan menentukan parah atau tidaknya gejala klinis yang timbul pada penderita infeksi parasit tersebut, seperti : derajat infeksi, lamanya infeksi, faktor hospes dan parasitnya sendiri. ${ }^{17}$ Infeksi yang belum lama terjadi, belum dapat mempengaruhi pertumbuhan tinggi badan seseorang.

Analisis dengan uji chi-square menunjukkan bahwa tidak terdapat hubungan yang bermakna $(p>$ $0,05)$ antara kejadian infeksi protozoa intestinal dengan status gizi pada murid SDN 02 dan 012 di Kecamatan Ulakan Tapakis tersebut berdasarkan indeks BB/TB.

Giardia lamblia merupakan jenis protozoa yang memiliki peran paling konsisten dalam menimbulkan malabsorbsi nutrien dibandingkan dengan protozoa lainnya. $^{2}$ Walaupun dalam penelitian ini Giardia lamblia merupakan protozoa yang paling banyak ditemukan, namun tidak ada hubungan yang signifikan antara infeksi protozoa intestinal tersebut dengan status gizi.

Hasil penelitian ini berbeda dengan penelitian di Selangor Malaysia terhadap 281 anak yang berumur 2-15 tahun. Pada penelitian tersebut didapatkan bahwa Giardiasis berhubungan dengan terjadinya wasting (rendahnya score BB/TB) pada anak. $^{16}$

Pada penelitian ini didapatkan bahwa pada anak yang positif terinfeksi protozoa intestinal lebih banyak yang memiliki gizi normal dibandingkan yang kurus. Infeksi Giardia lamblia dapat menimbulkan sindroma malabsorbsi, seperti: penurunan berat badan, kelelahan, kembung dan feses berbau busuk. Bahkan jika terus berlanjut, bisa terjadi gangguan pertumbuhan. Perbedaan hasil penelitian ini dapat disebabkan karena efek dari infeksi Giardia lamblia dapat berbeda diantara penderitanya, hal ini dipengaruhi oleh jumlah kista yang tertelan, Iamanya infeksi, faktor hospes dan parasitnya sendiri. ${ }^{17}$ Derajat infeksi yang ringan tidak akan begitu mempengaruhi berat badan seseorang secara akut.

\section{SIMPULAN}

Tidak terdapat hubungan antara infeksi protozoa intestinal dengan status gizi murid SDN 02 dan 012 di Kecamatan Ulakan Tapakis Kabupaten Padang Pariaman.

\section{UCAPAN TERIMA KASIH}

Terima kasih kepada Kepala Sekolah, seluruh guru dan siswa SDN 02 dan 012 Ulakan Tapakis yang telah banyak membantu penulis dalam pelaksanaan penelitian ini.

\section{DAFTAR PUSTAKA}

1. Anorital, Dewi RM, Ompusunggu S. Distribusi parasit usus protozoa di Kabupaten Hulu Sungai Utara Kalimantan Selatan. Media Penelitian dan Pengembangan Kesehatan. 2010;20:8-18.

2. Boeke CE, Mora-Plazas M, Forero Y, Villamor E. Intestinal protozoan infections in relation to nutritional status and gastrointestinal morbidity in Colombian school children. J Trop Ped. 2010; 56(5):299-306.

3. Mukhiya RK, Rai SK, Prajapati A. Intestinal protozoan parasitic infection among school children. J Nepal Health Res Counc. 2012; 10(22):204-7.

4. Al-Harazi T, Ghani MK, Othman H. Prevalence of intestinal protozoan infections among Orang Asli school children in Pos Senderut, Pahang, Malaysia. J Egypt Soc Parasitol. 2013;43(3):561-8.

5. Darnely, Sungkar S. Infeksi parasit usus pada anak panti asuhan, di Pondok Gede Bekasi. 2011;61(9): 347-51.

6. Nilamsari L. Perbedaan prevalensi protozoa usus antara siswa SD pedesaan dengan perkotaan dan hubungannya dengan faktor resiko (skripsi). Yogyakarta: Universitas Muhammadiyah; 2012.

7. Khairina. Gambaran infeksi protozoa intestinal pada anak binaan rumah singgah "Amanah" Kelurahan Rimbo Kaluang, Kecamatan Padang Barat Padang (skripsi). Padang: Universitas Andalas; 2006. 
8. Al-Mekhlafi HM, Al-Maktari MT, Jani R, Ahmed A, Anuar TS, Moktar N, et al. Burden of giardia lamblia infection and its adverse effect on growth of school children in rural Malaysia. Plos Neglected Tropical Disease. 2013;7(10): e2516.

9. Utami PD, Setianingsih H. Faktor-faktor yang berpengaruh terhadap kejadian infeksi parasit usus pada anak usia prasekolah di Kelurahan Kedung Cowek (daerah pesisir) Surabaya. Dalam: Widodo B, Setya W, Jaka S, editor (penyunting). Prosiding Seminar Nasional 2013 Menuju Masyarakat Madani dan Lestari; 2013 Des 18; Yogyakarta: DPPM UII; 2013. hlm. 555-64.

10. Natadisastra D, Agoes R, editor (penyunting). Parasitologi kedokteran ditinjau dari organ tubuh yang diserang. Jakarta: EGC; 2009.

11. Makalew YM, Kawengian SES, Malonda NSH. Hubungan antara asupan energi dan zat gizi dengan status gizi anak sekolah dasar kelas 4 dan 5 SDN 1 Tounelet dan SD Katolik St. Monica Kecamatan Lawongan Barat. [serial online] 2013 (diunduh Agustus 2015). Tersedia dari: URL: HYPERLINK http://fkm.unsrat.ac.id

12. Supariasa IDN, Bakri B, Fajar I. Penilaian status gizi. Jakarta: EGC; 2002.
13. Sebataraja LR, Oenzil F, Asterina. Hubungan status gizi dengan status sosial ekonomi keluarga murid sekolah dasar di daerah pusat dan pinggiran Kota Padang. Jurnal Kesehatan Andalas. 2014; 3(2):182-7.

14. Arisna, R. Hubungan trichuriasis dengan status gizi murid sekolah dasar negeri 08 Pasar Surantiah Kabupaten Pesisir Selatan (skripsi). Padang: Universitas Andalas; 2014.

15. Suomokil O. Hubungan pola makan dan asupan zat gizi dengan status gizi anak balita di pulau Nusalaut Kabupaten Maluku Tengah. [serial online] 2013 (diunduh Oktober 2015). Tersedia dari: URL: HYPERLINK http://etd.repository.ugm.ac.id

16. Al-Mekhlafi HM, Azlin M, Nor aini $U$, Shaik A, Sa'iah A, et al. Giardiasis is a predictor of childhood malnutrition in Orang Asli children in Malaysia. Trans R Soc Trop Med Hyg. 2005;99: 686-91.

17. Sutanto I, Ismid IS, Sjarifuddin PK, Sungka S. Buku ajar parasitologi kedokteran. Jakarta: Balai Penerbit FK UI; 2008.

18. Adriani R. Hubungan ascariasis dengan status gizi murid kelas I, II dan III sekolah dasar negeri No 12 Ulak Karang Utara Kecamatan Padang Utara (skripsi). Padang: Universitas Andalas; 2014. 